\title{
RELIGION AND INEQUALITY: THE ROLE OF STATUS ATTAINMENT AND SOCIAL BALANCE PROCESSES
}

\author{
LISA A. KEISTER \\ Duke University \\ DAVID EAGLE \\ Duke University
}

\begin{abstract}
Religion is an important determinant of social and economic inequality, but the mechanisms that underlie this relationship are not well-understood. Early scholars recognized this connection, but their ideas do not adequately explain contemporary stratification patterns. Recent research documents robust empirical relationships between religion and material outcomes but has not yet begun to identify causes of these patterns. We fill this gap by providing a theoretical explanation of the religion-inequality link that synthesizes ideas from early and recent sociology. We propose that the process is inherently multilevel. We draw on ideas from status attainment theory to develop a micro-model and ideas from social balance theory to aggregate the
\end{abstract}

Lisa A. Keister is the Gilhuly Family Distinguished Professor of Sociology at Duke University. She is an economic sociologist who conducts research on personal saving and asset accumulation, and she has a particular interest in understanding how personal ideologies, including religious ideologies, are associated with saving. David Eagle is a $\mathrm{PhD}$ candidate in the Department of Sociology at Duke University. He is a sociologist of religion whose focal research interests are in the social organization of American religion. His dissertation examines the causes and consequences of the increasing prevalence of megachurches in the United States. Contact can be directed to Lisa A. Keister at lkeister@soc.duke.edu. 
model's outcomes. The synthesis of ideas from these theoretical traditions provides a unique, and potentially useful way to understand the relationship between cultural orientation and material resources.

Religion plays a central role in creating and maintaining social and economic inequality, but the mechanisms driving this relationship are not well-understood. Weber's The Protestant Ethic and the Spirit of Capitalism (2002) contains the most famous early argument for a link between religion and inequality, but the ideas that he and other early theorists proposed have garnered significant critique. At the heart of Weber's thesis is the contention that changes in the religious orientation of Europeans through the influence of Protestantism, especially Calvinism, led to fundamental changes in the economic system. Scholars have challenged Weber's thesis on several grounds. Economic historians have argued that in many parts of Europe, the transition to capitalism preceded the emergence of reformed Protestantism (Bainton 1985; Samuelsson 1964). Therefore, it is equally plausible that the emergence of new forms of economic behavior produced changes in religious beliefs, or that religious and economic change are interdependent and often difficult to disentangle. Coleman (1990) criticizes Weber for positing a theory that claims individual beliefs straightforwardly aggregate into societal-level values. Such a simple process fails to account for how stratification develops, and how individual-level beliefs aggregate into different cultural orientations depending on one's social position.

Even if we disregard these internal problems, the religious landscape and the processes that account for stratification have changed considerably since Weber and his contemporaries developed their ideas. Looking only at patterns in North America, these theories cannot accommodate the decline of so-called mainline Protestant denominations, the proliferation of conservative Protestant groups, the impact of immigration on the composition of the Catholic Church, and the increased presence of other religious traditions. It has also become increasingly clear that the relationship between religion and stratification is not a function of large-scale shifts in the mode of production but rather reflects 
changing individual and group approaches to human capital, work, entrepreneurship, saving, and investing.

In the 1960 s, researchers revived questions about religion and inequality. However, these debates lost momentum when the convergence of the socioeconomic status (SES) of mainline Protestants and Catholics came to dominate the literature (Glenn and Hyland 1967; Lenski 1961; Roof and McKinney 1987). The more recent years have witnessed something of a renaissance in the study of religion and inequality. However, although contemporary research is empirically rich, it has paid relatively little attention to the causal processes linking religion and material outcomes. Modern data provide powerful evidence that religion affects education for adults (Chiswick 1988; Darnell and Sherkat 1997; Lehrer 1999b, 2004) and adolescents (Muller and Ellison 2001; Sherkat and Darnell 1999), gender roles in the home (Ellison and Bartkowski 2002; Read 2004) and in the labor market (Lehrer 1999a, 2000; Sherkat and Darnell 1999), fertility and family formation (Glass and Jacobs 2005; Lehrer 1996b, 1996c; McQuillan 2004), wages (Keister 2010; Smith and Faris 2005; Steen 1996; Wilder and Walters 1998), work and occupational outcomes (Smith and Faris 2005), and saving behavior and wealth (Crowe 2008; Keister 2003, 2007, 2008). Researchers have understandably taken advantage of modern data and methods to provide careful empirical support for key relationships that eluded prior generations of scholars. However, the resulting body of research contains a large amount of evidence for bivariate relationships but minimal discussion of how the interactions among variables produce social stratification. The theoretical discussion accompanying most of the empirical evidence contains an implicit status attainment model but rarely articulates or demonstrates causal processes linking religion and inequality. Moreover, contemporary researchers do not always adequately attend to the problems inherent in using individual-level data to draw inferences about group-level outcomes.

Our objective is to provide a contemporary theoretical explanation of how religion affects inequality. The first step in understanding this relationship is clarifying that there are separate but related processes operating at the individual (micro) and group (macro) levels. This starting point allows us to integrate ideas from 
early and contemporary research while moving beyond the challenges faced in both. We propose that micro-level processes connect religion to individual and family material well-being following a status attainment logic. We articulate the details of this model, discuss how important behaviors and processes are interrelated, and address how various processes interact to affect inequality. We pay particular attention to integrating the large amount of empirical evidence available from contemporary scholarship. Next, we show that ideas from social balance theory can explain how individual and family processes combine to produce group-level patterns. Finally, we specify the details of the balance model and discuss the implications for aggregate indicators of social inequality.

\section{Religion and Social Stratification: Two Levels of Aggregation}

Most efforts to explain how religion affects social stratification attempt to isolate either individual or group outcomes. Effective isolation of this sort is challenging because, under most circumstances, it requires focusing on one level of aggregation without invoking behaviors or outcomes at the other level. Early theorists attempted to isolate macro-level outcomes by addressing how national patterns of religious affiliation affected national patterns of economic organization (Sombart 1911; Weber 2002). Only a limited number of cases exist at the macro level, making comparison difficult. Additionally, it is difficult to collect data at the macro-level. Thus, in most cases, early theorists resorted to discussing how individual behaviors lead to aggregate patterns (Coleman 1990). More recent research focuses more narrowly on micro-level outcomes (e.g., individual income, family wealth) because these processes are essential to understanding contemporary stratification processes. Moreover, data are often collected at the level of individuals or other levels below that of the social system. Although contemporary explanations focus on micro-level explanations of micro-level outcomes, it is common to invoke macro-level causes (e.g., neighborhood, generational effects) or to draw conclusions about macro-level issues (e.g., group differences in income, work, wealth) from micro-level data without carefully specifying how the levels interact (Coleman 1990). 
An alternative to focusing on either the micro- or the macrolevel is to explicitly integrate both levels, creating a more complete model of the social system within which religion and inequality interact. Our goal with such a model is to (1) explain how grouplevel religious ideology affects individual orientations toward education, work, financial issues, and family decisions; (2) address how these orientations affect individual economic behavior; and (3) demonstrate how these behaviors aggregate to group measures of material well-being (e.g., education, income, wealth). Figure 1 provides a sketch of the system within which religion affects social stratification.

\section{Group religious ideology}

\section{Group SES} outcomes
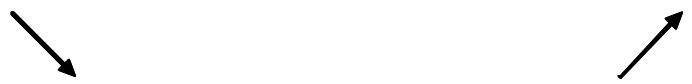

\section{Individual orientations \\ Individual behavior}

Figure 1. Religion and Material Outcomes

We draw on Coleman (1990) to provide the basic structure of the model. Group religious ideology operates through individual orientations, which in turn influence individual behaviors, which produce observed group-level differences. We incorporate relevant findings from contemporary research in social stratification that suggest micro-level processes are key to understanding group-level differences in status attainment.

\section{Micro Model}

\section{Key Concepts}

A status attainment model relating childhood and adult religion to education, work and occupational status, income, and wealth relates the individual and family processes that connect religious 
ideology to micro-level material outcomes (Figure 2). ${ }^{1}$ Status attainment refers to the process by which individuals arrive at socioeconomic standing over their lives, and the status attainment approach has become one of the most widely used theoretical perspectives in sociological research on social and economic wellbeing. Work in this tradition specifies individual traits or attributes, usually family background, education, and work behaviors that contribute to adult attainment. Although other theoretical models may potentially relate religious ideology and micro-level material outcomes, a growing body of related empirical evidence supports the status attainment model. Equally important, the status attainment model includes most of the important behaviors and processes that affect attainment, allows for interactions among these processes, effectively describes how family characteristics affect adult outcomes, and retains the appropriate time-ordering (e.g., family background affects education, which affects adult occupation). Because the status attainment model incorporates both individual/family and contextual influences on micro-outcomes, it also efficiently and accurately represents the macro-micro and micro-micro links pictured in Figure 1.

In the status attainment model, childhood religion refers to affiliation, belief, practice, congregation traits, and the broader religious environment. Affiliation is the religious denomination or tradition with which an individual is associated. In the United States, persuasive evidence shows that members of religious groups behave similarly in consequential ways (Burstein 2007; Glass and Jacobs 2005; Keister 2008; Lehrer 2009; Smith and Faris 2005). A long history of research shows that affiliation with mainline Protestant, conservative Protestant, black Protestant, Roman Catholic, Jewish, or other religious groups affects wellbeing (Herberg 1983). The proliferation of Protestant denominations in recent decades and fluctuations in the sizes of some denominations and traditions suggests that it is becoming increasingly important to also consider more precise information about religious affiliation (Smith and Faris 2005). For instance,

\footnotetext{
${ }^{1}$ Although our research focuses on how religion affects individual and family SES, we realize that other processes are at work. For example, research has documented that SES affects religious affiliation, particularly for adults.
} 

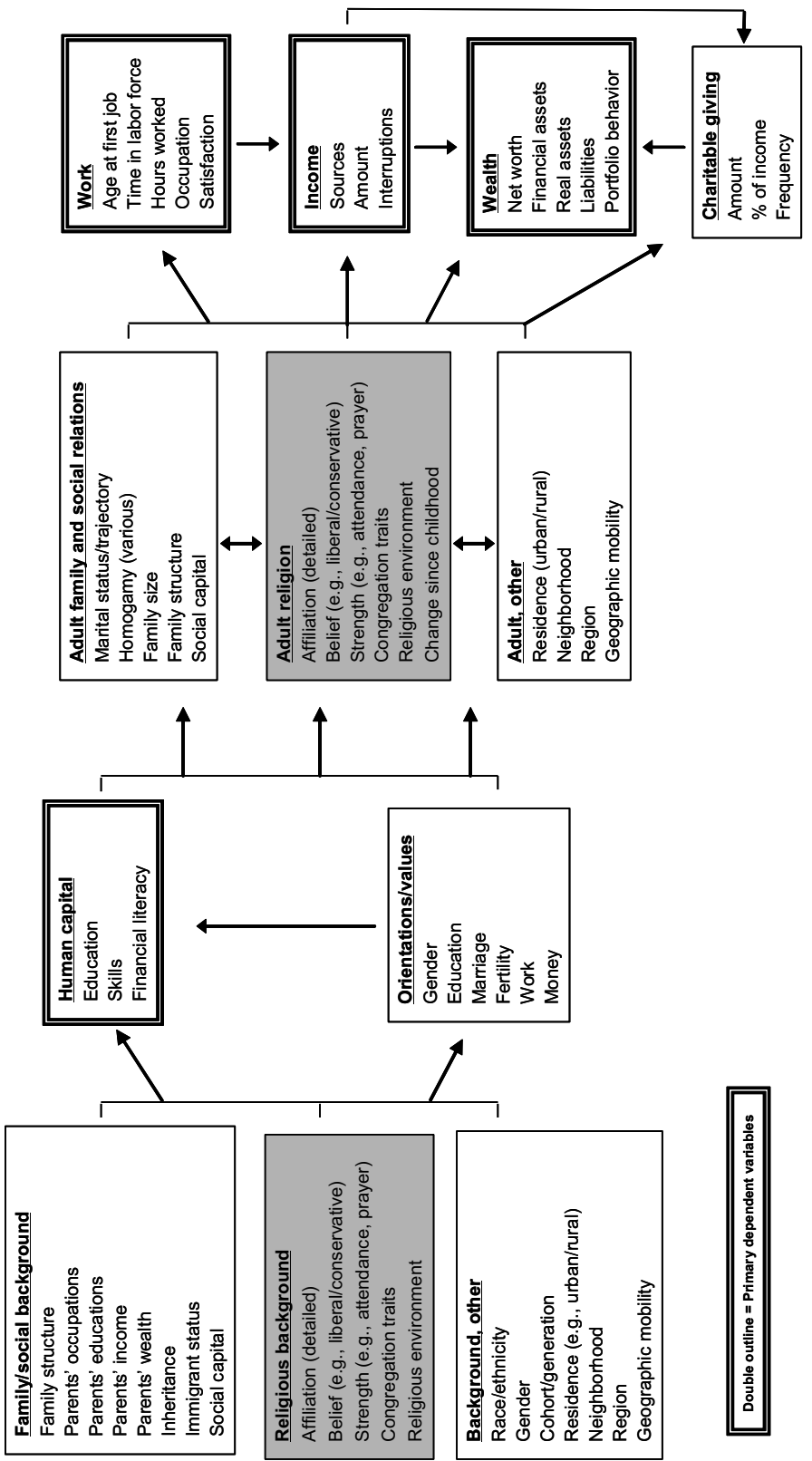

Figure 2. The Individual-and Household-Level Attainment Model 
patterns vary for those affiliated with more narrowly defined traditions. One line of research documents how members of the Church of Jesus Christ of Latter Day Saints have divergent economic trajectories from other conservative groups (Smith and Faris 2005).

Religious belief and practice, congregation traits, and religious environment also influence the individual and family processes that affect well-being. Belief is the substance or content of religious ideas (e.g., belief that the Bible is the inerrant word of God). The strength of religious conviction is the importance of religious belief to the individual and is usually measured as religious practice such as the frequency of attendance at religious services. Congregation traits (e.g., size, socioeconomic class, beliefs) have become increasingly important in understanding how religion affects wellbeing as the size of denominations grows and diversity within denominations expands (Chaves and Miller 1999; Edgell 2006; Park and Reimer 2002; Reimer 2007). Religious environment refers to the broader religious context and the position of a denomination or congregation in that context. For instance, membership in a denomination that is growing in size or enjoying greater social acceptance is likely to have different implications than membership in a denomination that is decreasing in size or falling out of social favor (D'Antonio, Hoge, and Davidson 2007; Hout, Greeley, and Wilde 2001; Roof and McKinney 1987). Both congregations and religious environments are elements of the context (i.e., macrolevel) that affect micro orientations and outcomes (depicted in Figure 2).

Family and social background traits are also important elements of the micro model. Family structure during childhood, parents' socioeconomic status (including occupations, education, income, and wealth, family immigrant status, and social capital/relations combine to shape childhood experience. ${ }^{2}$ In addition, sociological research has demonstrated that race/ethnicity, gender, and other individual attributes affect

\footnotetext{
${ }^{2}$ Family and household groups are treated in various ways in multilevel models. We include families and households as part of the aggregate level. However, we include family background and adult family traits as characteristic of the individual in the micro model, consistent with status-attainment literature.
} 
attainment levels and trajectories. ${ }^{3}$ Research has also demonstrated that families transmit cultural capital (Jaeger 2009), which plays an important role in status attainment. Figure 2 depicts contextual factors as part of the background traits that affect micro-level outcomes. Membership in a birth cohort or generation, residence in an urban or rural area, neighborhood, and region of the country are integral parts of the attainment process. Similarly, mobility among different areas during childhood and adolescence can affect the way the attainment process unfolds. Moreover, contextual factors such as congregation and religious environment are elements of the macro-level situation in which micro-level attainment processes occur.

Combined with other traits, childhood religion helps produce human capital and values or orientations. Human capital is an intermediary outcome that operates as both an initial outcome and an explanatory factor in predicting subsequent outcomes. Human capital includes characteristics of formal education (e.g., attainment, private versus public, timing), skills, training, work experience, and related traits. Human capital also captures the notion of financial literacy (i.e., acquired knowledge related to budgeting, saving, and investing) that is particularly important in understanding saving behavior and wealth accumulation.

Orientations, or values, are guiding principles or ideals that express the worth associated with particular actions or outcomes(Joas 2000; Maio et al. 2003; Schwartz and Bilsky 1987). They are directed toward particular behaviors or states and follow from religion, which is a more general orienting approach or ideology (Hitlin 2003; Hitlin and Piliavin 2004; Joas 2000; Kohn et al. 2000). Notions of values and orientation fell out of favor in sociology, including in the sociology of religion, following some controversial uses of the terms decades ago. However, the terms are receiving a more favorable reception in current research that has demonstrated that values are essential to understanding, among other processes, how religion affects behaviors and outcomes. For instance, there is evidence that religion is associated with

\footnotetext{
${ }^{3}$ Race and ethnicity can be considered individual or family traits, particularly in religions where congregations and denominations cluster around people with similar racial and ethnic backgrounds. The process described here is the same regardless.
} 
orientations toward gender roles in the home and in the workplace (Glass and Jacobs 2005; Lehrer 1995; Peek, Lowe, and Williams 1991; Sherkat 2000), education and educational attainment (Chiswick 1988; Darnell and Sherkat 1997; Glass and Jacobs 2005; Lehrer 1999b), marriage and fertility (Marcum 1981, 1986; Sherkat and Darnell 1999), and parent-child relations (Bartkowski and Read 2003; Ellison, Bartkowsi, and Segal 1996; Ellison and Sherkat 1993). Religious beliefs also affect orientations toward work and money. That is, beliefs express preferences regarding desirable occupations, acceptable work behavior, work-family balance issues, sacrificial giving, how money affects prospects for the afterlife, and the desirability of saving from current income(Crowe 2008; Keister 2007, 2008; Maio et al. 2003). ${ }^{4}$

As Figure 2 indicates, human capital and orientations/values affect material outcomes through adult family and social relations, adult religion, and other individual and contextual traits. Adult family includes marital status and trajectory, marital homogamy (e.g., religious, educational, occupational), family size and structure, and social capital. Adult religion refers to religious affiliation, beliefs, and practices as well as congregation traits and religious environment. For many, childhood and adult religion will be the same, but religious change can also affect adult well-being (Roof 1989). Charitable giving includes the dollar amount of donations to religious and other charitable organizations, the percent of income dedicated to charitable giving, and the frequency of contributions.

The model explicitly identifies four measures of well-being on which individuals and groups are stratified: human capital, work and occupation, income, and wealth. However, other dimensions could be incorporated into the model as well. Similarly, individual and family traits that appear in the model, but not identified as outcomes in Figure 2 (e.g., gender, race), could be explicitly discussed. Gender and race are both strongly commingled with religious affiliation and beliefs and are also among the most enduring determinants of attainment and life trajectories. Although

\footnotetext{
${ }^{4}$ There is an increasing amount of literature that focuses more directly on identifying, measuring, and understanding values (Hechter 1993; Inglehart and Baker 2000; Schwartz and Huismans 1995).
} 
we do not discuss them in great length here, gender and race could easily be the focus of empirical exploration using this model. Human capital is an important intermediary concept that is an outcome itself and that also contributes to work and occupational well-being, income, and wealth. Work refers to childhood and adult jobs, including age at first employment, time spent in the labor force (and its corollary: time spent out of the labor force involuntarily), hours worked, and occupational prestige. Income refers to total monetary flows into the household (e.g., earned income versus government transfer payments) as well as categorical indicators related to income (e.g., the occurrence and frequency of income interruptions). Wealth is total net worth (total assets less total liabilities) as well as measures of financial assets (net worth less equity in owner-occupied housing), real assets (housing and other tangibles), and liabilities (consumer debt, mortgage debt, business debt). Wealth also includes categorical indicators (e.g., measures of portfolio composition).

\section{Micro Model: Mechanisms}

In this model, religion affects material outcomes through several channels. The cultural understandings that accompany religious beliefs can influence well-being through demographic behaviors that facilitate or impede human capital acquisition, career advancement and other work behaviors and outcomes, income, and wealth ownership. Religion affects orientations toward education, the attainment of formal education, and the acquisition of other types of training, experience, and expertise (Burstein 2007; Darnell and Sherkat 1997; Glass and Jacobs 2005; Lehrer 1999b). Religion influences sexuality and fertility, including the onset of sexual activity, age at first birth, and family size (Lehrer 1996a; Marcum 1981; Sherkat and Darnell 1999). Religion affects parenting styles and relationships between parents and their children (Bartkowski and Ellison 1995; Ellison and Sherkat 1993). Religion influences age at first marriage, marital stability, and the likelihood of separation and divorce (Call and Heaton 1997; Lehrer 1996a). There is also a strong relationship between religion and gender roles (D'Antonio et al. 2001; Hertel and Hughes 1987; Peek, Lowe, and Williams 1991), including female educational attainment and labor force participation particularly when children 
are young (Glass and Jacobs 2005; Lehrer 1995; Sherkat 2000). These processes combine to influence occupational advancement, income, other financial benefits, the availability of funds to save, and wealth accumulation, particularly in faiths where religious homogamy is high (Lehrer 1996a).

Religion can influence material well-being by shaping values and orientations toward work and occupation, budgeting, consumption, charitable giving, debt, saving, and asset accumulation (Crowe 2008; Glass and Jacobs 2005; Keister 2008; Read 2004). Religious beliefs affect the relative prestige of certain occupations (e.g. working as a minister, or a career missionary) and organizations (e.g. religiously based charities). Religious beliefs also influence notions of the relative importance of work and family commitments and time allocation, the willingness to relocate to improve job prospects and career advancement, the desirability of self-employment, and the relative importance of income, advancement possibilities, and job content (Edgell 2006; Glass and Jacobs 2005; Johnson 2001; Keister 2007). Religious beliefs also affect orientations toward money and financial decisions including budgeting, active saving, the importance of charitable giving, the selection of worthwhile charities, and the amount of money given to charities (Chaves 1999; Hoge et al. 1999; Keister 2008). The value associated with particular work and financial behaviors varies dramatically by religious affiliation and belief, but there is little question that money is meaningfully connected to values and orientations both implicitly and explicitly (Peifer 2011; Wuthnow 1994; Zelizer 1978,).

Religion can also affect material well-being through social contacts. Children learn from their parents and others with whom they are associated how to approach education, work, and financial decision-making, including savings behaviors and ideas about the appropriateness of debt (Cavalli-Sforza 1993; Chiteji and Stafford 1999, 2000; Keister 2008). Parents and teachers affect children's perspectives on education and work through the structuring of children's activities both at home (Lareau 2002, 2003) and in the classroom (Willis 1981). Parents' jobs and their attitudes toward those jobs also convey class-based information to children that have the potential to affect socioeconomic attainment (Kohn 1976; Kohn and Slomczynski 2001; Kohn et al. 2000). Parents and other 
adults also convey information about saving and investing that affects how children approach money. Financial literacy is learned, and people who are not exposed to positive lessons regarding financial literacy at home, in church, or in school may be at a disadvantage in accumulating wealth.

Finally, because there is often stability between parents and their children in terms of religion and SES there are powerful intergenerational processes that intensify the relationship between religion and material outcomes. Occupational and earnings similarity across generations is high. Parents with high education and incomes have children with high educations and incomes. Parents with wealth bequeath their assets to their children, and the saving behavior of prior generations will determine inheritance size: those brought up in religious communities where savings is low will inherit less than those in groups where saving is high. Parents also transfer their religious beliefs to their children. Many Americans remain affiliated with the religions in which they were raised and marry others who were raised in similar faiths. Religion also creates social contacts. Depending on the religious environment, this can provide information about educational opportunities, jobs, business opportunities, or sources of capital that facilitate achievement. In contrast, in faiths where overall achievement levels are limited, the lack of consequential social ties may create a disadvantage. Adult religious affiliation and involvement may intensify and reinforce the values learned during childhood, especially when both members of a couple were raised in the same faith.

Although we discuss these processes as isolated, many of these behaviors and events interact with each other or occur simultaneously. People often make decisions regarding education, marriage, fertility, union dissolution, and related behaviors simultaneously. For example, decisions regarding marriage often involve simultaneous decisions about fertility, labor force participation, and saving. Moreover, there are likely to be meaningful interactions among the various behaviors and processes represented in the model. Lehrer $(2004,2009)$ has articulated how religious affiliation relates to various demographic processes and resulting measures of attainment. She proposes that investments in human capital, fertility behavior, union formation and dissolution, 
and other demographic processes are interrelated behaviors and that internalized religious teachings affect the perceived costs and benefits associated with these decisions. Expanding on details about which variables interact and how to test the simultaneous processes implied here are beyond the scope of this paper, but future research might usefully address these issues.

\section{Micro Models and Group-Level Outcomes}

The status attainment model presented so far identifies the processes that relate religious ideology to micro-level material outcomes, but it does not explain how these processes aggregate to group patterns (e.g., group-level income, education, occupational prestige; measures of inequality in these and other outcomes). The aggregation problem in this case is identifying the process by which the members of certain religious groups also share similar economic outcomes (e.g., education, skills, income, occupational traits, income, and wealth). The reasons that groups and their members consistently share ideologies, skills, and material outcomes is complex, involving a large number of processes. Moreover, ideologies are not transferred in the same way that skills and material outcomes typically are. The transfer of an ideology involves both interpersonal transmission processes and individual acceptance (or rejection) of the tenets of the ideology (Joas 2000; Maio et al. 2003; Schwartz and Bilsky 1987). Children usually adopt the ideology most common in the family, and as result, young children and their parents tend to have similar perspectives on many issues. However, over the life course many people alter their religious and ideological perspectives (Maio et al. 2003; Schwartz and Bilsky 1987). Although structural impediments may be relatively deterministic in the intergenerational transmission of education, income, and wealth, there is a great deal more freedom with respect to religious ideas. For example, transitioning from being a low- to high-wage earner may be much more difficult than transitioning from a Christian ideology to a non-religious ideology.

\section{Linking Micro and Macro: Social Balance Theory}

Linking micro-level processes and behaviors to macro-level outcomes requires an understanding of how changes in the social composition of a group impact its stated ideology. Ideas from 
social balance theory provide a valuable starting point for understanding how groups change (Johnsen 1986; Moody 1998). The starting point for balance theory is the idea that interactions in social groups, particularly in triads, tend toward balance (Heider 1946, 1958). That is, the underlying principle of the theory is that people tend toward balanced relations and away from imbalanced relations. In a balanced triad, all parties have the same affect toward all other parties. One example is the well-known pattern that dictates "a friend of a friend is a friend." That is, if person A and person $\mathrm{B}$ are friends, and person $\mathrm{A}$ and person $\mathrm{C}$ are friends, then person $\mathrm{B}$ is likely to be friends with person $\mathrm{C}$. Balance theory also has implications for social dynamics. For instance, if a triad is balanced (e.g., A, B, and C are all friends) and one of the relations changes (e.g., A and B sever their friendship), balance theory indicates that the remaining relations will also change until balance is regained (e.g., either A and B will resume their friendship).

Balance theory is also useful for understanding how groups interact with ideas, such as religious ideas. In this pattern $\mathrm{A}$ is the group identity on a particular issue, $\mathrm{B}$ is the aggregation of the group's beliefs about an idea, and $\mathrm{C}$ is the idea itself. The rules of social balance operate as they do with three people. For example, if a church (A) has traditionally seen the acquisition of wealth as "sinful" (C) but outside economic forces generate increased economic success among the church's members, the average economic status of the members (B), will increase. Now tension exists between the group's identity and the composition of the group. Social balance theory predicts that this tension will initiate a process where A and B are brought back in line. The church might change its official opinion, reject the more successful members, or downplay the significance of I. This pattern is a process that occurs over time and may be contested by involved parties. Therefore, a specific path to restore balance may take several forms. Imagine, for example, a group of adolescents who leave home for the first time to attend college. All these adolescents are members of the same church, and they share a religious ideology with their church, creating a balanced triad. However, when the adolescents arrive at college they may encounter new religious ideas. If these adolescents return to their church with a different set of religious ideas, it will create tension and the system will seek resolution. 


\section{Social Balance Model: Key Concepts}

Groups have three traits that are relevant to understanding the balance model: dominant ideologies, dominant skill sets, and shared rules. Groups share various ideologies, or general orienting statements (Maio et al. 2003; Schwartz and Huismans 1995; Schwartz, Struch, and Bilsky 1990). Liberal and conservative ideologies, for example, are broad theoretical constructions that subsume more specific values (i.e., statements of ideals) and attitudes (i.e., feelings or beliefs toward specific states and behaviors (Maio et al. 2003). A conservative religious ideology might include attaching high importance to traditional family values and a positive attitude toward women staying out of the labor force when their children are young. The group may have different ideologies for different arenas (e.g., religion, economics, politics) and corresponding values and attitudes. A group's dominant ideology refers to the ideology within each arena that is the most influential in the group. In most cases, a majority of group members will adhere to the ideology, but it is not necessary for the ideology to be shared by the majority. Groups may employ a variety of rationalizations to explain the difference.

Groups also have dominant skill sets, such as education, that characterize the majority of members. Shared ideologies are likely to include orientations toward certain skills (e.g., educational attainment is desirable) that encourage members to develop skills and that contribute to skill overlap within a group. Finally, groups have shared rules, both formal and informal, that develop to maintain order and to identify the group's goals and priorities. Formal rules, or laws, are codified and enforced through formal channels (e.g., a formal prohibition by a religious group against same-sex marriage). Informal rules, or norms, are not codified and are enforced through social sanctioning (e.g., a norm that women are primarily responsible for childcare).

\section{Social Balance Model: Initial Balance}

The balance model of people, groups, and religion begins in a state of social balance: the individuals and the group initially tend to share a positive affect toward a particular ideology. People are born into multiple groups (e.g., families, churches, neighborhoods). As the status attainment model suggests, these early group 
experiences provide starting points for both individual ideologies and skills. Children adopt the ideologies and orientations toward skills that are most common in their families and other groups for several reasons. First, children have few alternatives. As the status attainment literature demonstrates, children are exposed to a limited number of ideological options early in life, these options vary predictably by social class (Kohn 1959; Lareau 2003). Second, because children tend to like and identify with their parents (Gecas and Seff 1990), they are likely to emulate their parents' perspectives. Third, groups use formal and informal sanctions to encourage conformity. Social sanctioning can be as seemingly innocent as correcting a child who expresses a contrary opinion (e.g., there must not be a God), or more intense and consequential (e.g., excommunicating a member for homosexual behavior). Triad A pictured in Figure 3 illustrates this initial state. This triad is balanced because the group (G1) and the individuals (I) both have a positive affect toward the ideology (ID1) and toward each other. The figure simplifies the process by including only one collection of individuals, one group, and one ideology. We address multiple, overlapping group memberships below.

\section{Change and Rebalancing}

Over time, exogenous factors can lead individuals to adopt new ideologies or cause the dominant group ideology to change. The status attainment model identifies important points at which exogenous factors might lead to individual-level change such as a broadening of opportunities to pursue higher education, a change in local economic conditions, and the increasing cost of raising children. Similarly, new group leaders might introduce alternative orientations to a group, or denominational controversies may force congregations to clarify their position on issues that were previously downplayed. In either case, there is a possibility that the exogenous factor will lead to imbalance in the triad. Balance theory offers an explanation of the interpersonal processes that result. Figure 3 illustrates that the triad may become unbalanced in one of two ways: (1) if, on average, the individuals in the group adopt a negative affect toward ID1 (pictured in triad C1), or (2), if the group adopts a negative affect toward ID1 (pictured in triad C2). Both triads $\mathrm{C} 1$ and $\mathrm{C} 2$ include an uncertain relationship between 


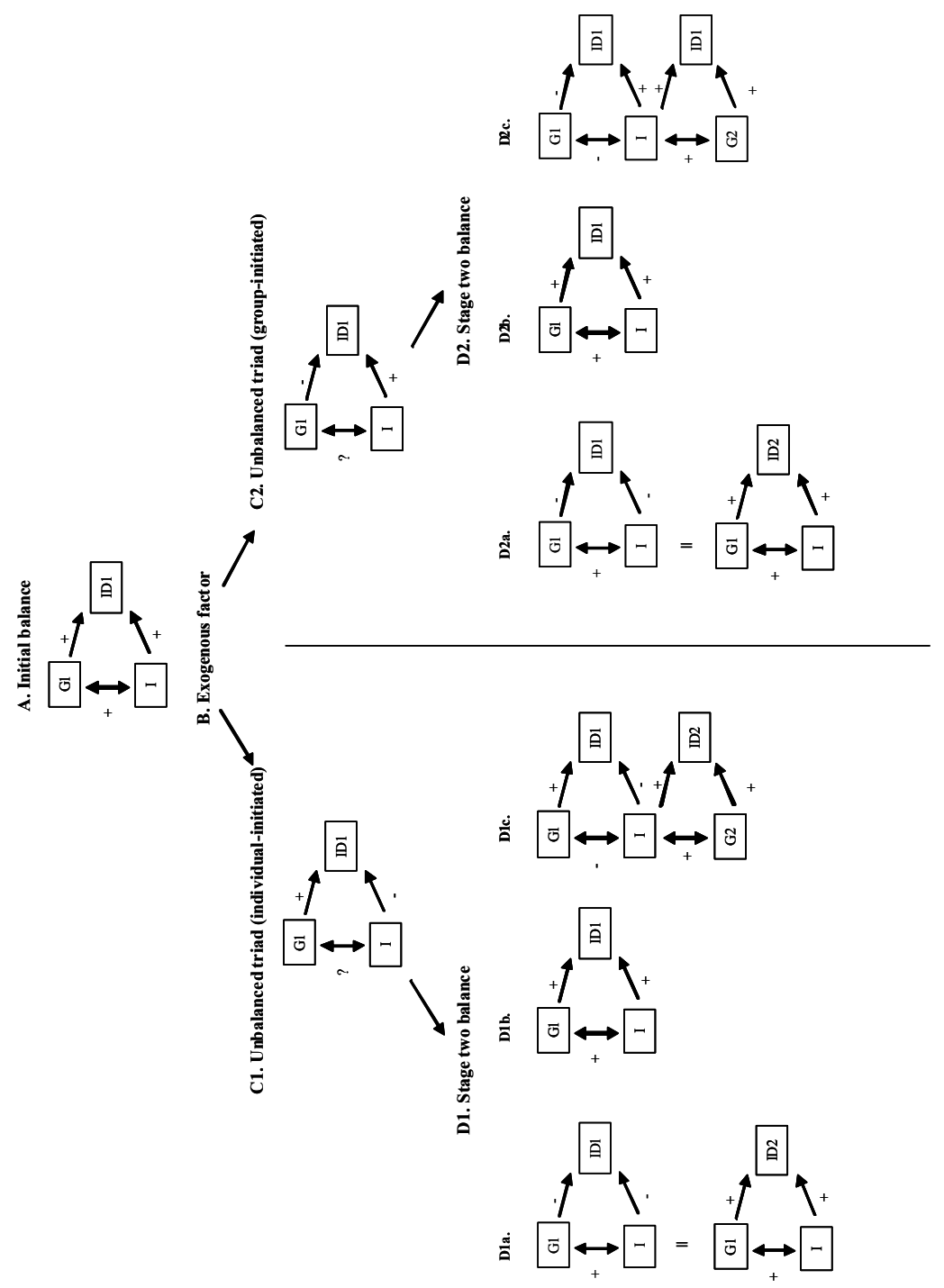

Figure 3. Aggregating to Group Outcomes with Balance Theory 
the individuals and group resulting from their inconsistent affects toward ID1.

\section{Resolving individual-initiated imbalance}

Balance theory suggests that there are several possible resolutions to the individual-initiated imbalance pictured in $\mathrm{C} 1$. The triads pictured in D1 represent the possible outcomes given that the imbalance was individual-initiated $(\mathrm{C} 1)$. Each D1 and D2 triad indicates a new time period and a triad that has returned to balance. The first resolution to the imbalance pictured in $\mathrm{C} 1$ is shown in D1a and indicates that the group also adopts a negative affect toward ID1. That is, the group changes its orientation toward the ideology to match the new majority opinion of its members. The upper and lower triads labeled D1a are equivalent. The upper triad indicates both the individuals and the group adopt negative affects toward the original ideology (ID1), and the lower triad indicates that they both adopt a positive affect toward a new ideology (ID2). Therefore, if both the individuals and the group still disagree but decide to downplay the importance of ID1, they agree. Moreover, a negative affect toward ID1 can be considered a different ideology (and labeled ID2). In either case, the outcome is renewed balance.

The second possible resolution to the imbalance pictured in $\mathrm{C} 1$ is that the individual returns to his or her original affect toward ID1 (pictured in D1b). For example, students returning from college with new religious ideas might again adopt a positive affect to their group's dominant ideology once back in the community. The triad pictured in D1b is, therefore, identical to the initial triad (A). The third possible resolution to the imbalance pictured in $\mathrm{C} 1$ is shown in D1c. In this outcome, the individuals adopt a negative affect toward the group and continue to hold a positive affect toward the new ideology (ID2). This is equivalent to the individuals adopting a positive affect toward a new group (G2) and a new ideology (ID2). This potential outcome is exemplified by the students who adopt new religious ideas at college, return home, and start a new religious group based on these new ideas. Negative feelings toward the community of origin and positive feelings to the new group results. 
Resolving group-initiated imbalance

There are also several resolutions to the imbalance pictured in $\mathrm{C} 2$, which occurs when the orientation of the group toward the original ideology becomes negative. First, it is possible that the individuals will also adopt this new affect toward the original ideology (pictured in D2a). This resolution implies that the majority of individuals decided to go along with the dominant group opinion. As Figure 3 suggests, this is equivalent to both the group (G1) and the individuals adopting a positive affect toward a new ideology (ID2). Imagine, for example, that a denomination forces a congregation to take a pro-life position on abortion, an issue the group has not discussed because members of the church have contrasting views. Dissenting members of the group might be convinced after a reconsideration of this issue and adopt the resolution. The second possible resolution to the imbalance pictured in C2a is a return to the initial balance (pictured in D2b and A). This implies that the dominant group perspective returns to its original state. It follows that the triad is again balanced if the individuals retain a positive affect toward the initial position. The third resolution to the group-initiated imbalance is for the group to retain its negative affect toward the original ideology (ID1), a subset of individuals to retain a positive affect toward the ideology, and the group and this subset of individuals to adopt a negative affect toward each other (i.e., these individuals leave the group, and the group does not attempt to retain the lost members). This resolution is pictured as D2c, an outcome that is equivalent to the individuals joining a new group (G2) whose members are positively predisposed toward ID1.

\section{Impetus for change}

Change occurs when the individuals and the group drift apart. When the level of difference between individuals and the group on ideology or skills becomes intolerable to consequential individuals or to the majority of group members, the relationship will be perceived as imbalanced and change will occur. Of course, not all individuals in a group have exactly the same ideologies, always

\footnotetext{
${ }^{5}$ Membership in multiple groups is common, and an imbalance in one group can lead to imbalance in other groups. Each group would return to balance through the same process.
} 
follow all the rules, or have identical skillsets. However, social balance processes suggest that groups will be similar on these traits, downplay the significance of areas where differences are present, and change will occur when the difference becomes intolerable.

\section{Conclusion}

Religion is a critical determinant of social and economic inequality, and theorists across the social sciences have speculated about its role for decades. Despite this longstanding interest, there is still little consensus on the mechanisms that account for the religion-inequality relationship. Recent research provides compelling and mounting evidence of strong empirical patterns relating religious affiliation, religious beliefs, and religiosity to a host of SES indicators. However, this work has not yet moved beyond providing careful empirical evidence to explore the causal processes that underlie the patterns found in contemporary data. This article provides a contemporary, multilevel, causal model, which explains how religion affects inequality. We argue that micro-level processes link religion to individual and family material outcomes following a status attainment model. We also provide the details of the components of the model that link the various elements. We propose that the aggregation of individual and family processes to group outcomes can be understood using social balance theory. We argue that exogenous factors that change either the group composition or the group's ideology initiate social imbalance between the composition of the group's members and the group's official position. Social imbalances seek resolution, and so if the group changes its ideology or members change their ideas, the significance of the tension is downplayed, or dissenting members leave the group.

This work contributes to understanding differences across people and groups in economic attainment and the important role that religious ideology plays in shaping well-being. More centrally, this paper contributes to understanding the relationship between cultural orientation and material resources. This model addresses the process by which individuals and the groups to which they belong can remain wealthy or poor. This work also contributes to understanding social processes more generally. Status attainment 
has become taken-for-granted in research aimed at understanding individual and family well-being, but it is seldom paired with other perspectives on social behavior to understand its position relative to other social systems. Likewise, although Coleman's model of the interaction between micro and macro processes has become well-known, few studies have explored how the aggregation of individual and family processes happens. Finally, social balance theory is widely used in some circles, but it does not typically play a central role in theories of stratification or religion. In this paper, we draw on ideas from each of these perspectives to develop a model that can answer critical social questions.

Future research could empirically test many of these ideas using studies such as the National Longitudinal Study of Adolescent Health, which includes information on religion, social networks, and short- and long-term socioeconomic standing. Empirical exploration of these issues will naturally raise related concerns that data analysis will usefully adjudicate. For example, empirical exploration of the patterns of interaction among variables will demonstrate which interactions are relevant in which settings. Future work might also extend ideas from either the micro- or macro- portions of the model to motivate further theoretical research. The evidence suggests that unique values regarding work and money combined with amenable demographic behaviors (e.g., educational attainment, stable marriage, and high female labor force participation) afforded Roman Catholics considerable upward mobility in the wealth distribution in recent decades. However, we know little about the practices that lead some religious groups to accumulate relatively high-value wealth portfolios. For example, Mormons tend to be religiously conservative, but there is little evidence that they are asset-poor. We know little about how individual decisions and processes for these groups aggregate to group outcomes. Using the model described here to contrast Mormons with other conservative Protestants might yield insights into the behaviors and values that affect saving behavior and wealth ownership.

Similarly, the growth of suburban megachurches has created a growing group of people who call themselves Conservative Protestants but who tend to be higher SES than the typical American conservative Protestant. Moreover, people affiliated with 
the Jewish tradition tend to have relatively high net worth, but there are significant differences in wealth accumulation between Reform, Conservative, and Orthodox Jews. The causal pathways that undergird each of these patterns are not well understood. We know very little about the effects of other religious traditions, including Buddhism, Islam, and Hinduism, on material well-being. The approach described in this paper could usefully address these groups and may illuminate unique aggregation processes within these groups. Research along these lines could also help differentiate religious influences from ethnic processes.

\section{Acknowledgements}

Dr. Keister acknowledges a grant from the National Science Foundation (SES-1322738) that supported this research. 


\section{References}

Bainton, Roland. 1985. The Reformation of the Sixteenth Century. Boston, MA: Beacon Press.

Bartkowski, John P. and Christopher G. Ellison. 1995. "Divergent Perspectives on Childrearing in Popular Manuals: Conservative Protestants vs. the Mainstream Experts." Sociology of Religion 56:21-34.

Bartkowski, John P. and Jen'nan Ghazal Read. 2003. "Veiled

Submission: Gender, Power, and Identity among Evangelical and Muslim Women in the United States." Qualitative Sociology 26:71-92.

Burstein, Paul. 2007. "Jewish Educational and Economic Success in the United States: A Search for Explanations." Sociological Perspectives 50:209-228.

Call, Vaughn R. A. and Tim B. Heaton. 1997. "Religious Influence on Marital Stability." Journal for the Scientific Study of Religion 36:382-392.

Cavalli-Sforza, L. Luca. 1993. "How are Values Transmitted?" Pp. 305-318 in The Origin of Values, edited by M. Hechter, L. Nadel, and R. Michod. New York, NY: Aldine de Gruyter.

Chaves, Mark. 1999. "Religious Congregations and Welfare Reform: Who Will Take Advantage of 'Charitable Choice'?" American Sociological Review 64:836-846.

Chaves, Mark and Sharon L. Miller. 1999. Financing American Religion. Walnut Creek, CA: AltaMira Press.

Chiswick, Barry R. 1988. "Differences in Education and Earnings Across Racial and Ethnic Groups: Tastes, Discrimination, and Investments in Child Quality." Quarterly Journal of Economics 103:571-597.

Chiteji, Ngina S. and Frank P. Stafford. 1999. "Portfolio Choices of Parents and Their Children as Young Adults: Asset Accumulation by African American Families." American Economic Review 89:377-380.

Chiteji, Ngina S. and Frank P. Stafford. 2000. "Asset Ownership Across Generations." Working Paper, Jerome Levy Institute, Annandale-on-Hudson, NY. 
Coleman, James S. 1990. Foundations of Social Theory. Cambridge, MA: Harvard.

Crowe, Christopher. 2008. "Asset Prices and Armageddon: Do Evangelicals' 'End Times' Beliefs Affect U.S. Housing Prices?" Working Paper, International Monetary Fund, Washington, DC.

D'Antonio, William V., James D. Davidson, Dean R. Hoge, and Katherine Meyer. 2001. American Catholics: Gender, Generation, and Commitment. Walnut Creek, CA: AltaMira Press.

D'Antonio, William V., Dean R. Hoge, and James D. Davidson. 2007. American Catholics Today: New Realities of Their Faith and Their Church. Lanham, MD: Rowman and Littlefield.

Darnell, Alfred and Darren E. Sherkat. 1997. "The Impact of Protestant Fundamentalism on Educational Attainment." American Sociological Review 62:306-315.

Edgell, Penny. 2006. Religion and Family in a Changing Society. Princeton, NJ: Princeton University Press.

Ellison, Christopher G. and John P. Bartkowski. 2002.

"Conservative Protestantism and the Division of Household Labor Among Married Couples." Journal of Family Issues 23:950-985.

Ellison, Christopher G., John P. Bartkowsi, and Michelle L. Segal. 1996. "Conservative Protestantism and the Parental Use of Corporal Punishment.” Social Forces 74:1003-1028.

Ellison, Christopher G. and Darren E. Sherkat. 1993.

"Conservative Protestantism and Support for Corporal

Punishment” American Sociological Review 58:131-144.

Gecas, Victor and Monica A. Seff. 1990. "Families and Adolescents: A Review of the 1980s." Journal of Marriage and the Family 52:941-958.

Glass, Jennifer and Jerry Jacobs. 2005. "Childhood Religious

Conservatism and Adult Attainment among Black and White Women." Social Forces 84:555-579.

Glenn, Norval D. and Ruth Hyland. 1967. "Religious Preference and Worldly Success: Some Evidence from National Surveys." American Sociological Review 32:73-85. 
Hechter, Michael. 1993. "Values Research in the Social and Behavioral Sciences." Pp. 1-30 in The Origin of Values, edited by M. Hechter, L. Nadel, and R. Michod. New York, NY: Aldine de Gruyter.

Heider, Fritz. 1946. "Attitudes and Cognitive Organization." Journal of Psychology 21:107-112.

Heider, Fritz.1958. The Psychology of Interpersonal Relations. New York, NY: Wiley.

Herberg, Will. 1983. Protestant-Catholic-Jew: An Essay in American Religious Sociology. Chicago, IL: University of Chicago Press.

Hertel, Bradley R. and Michael Hughes. 1987. "Religious Affiliation, Attendance, and Support for 'Pro-Family' Issues in the United States." Social Forces 65:858-882.

Hitlin, Steven. 2003. "Values as the Core of Personal Identity:

Drawing Links between Two Theories of Self." Social Psychology Quarterly 66:118-137.

Hitlin, Steven and Jane Allyn Piliavin. 2004. "Values: Reviving a Dormant Concept." Annual Review of Sociology 30:359-393.

Hoge, Dean R., Charles Zech, Patrick McNamara, and Michael J. Donahue. 1999. "Giving in Five Denominations." Pp. 3-10 in Financing American Religion, edited by M. Chaves and S. L. Miller. London, England: Sage Publications.

Hout, Michael, Andrew Greeley, and Melissa J. Wilde. 2001. "The

Demographic Imperative in Religious Change in the United States." The American Journal of Sociology 107:468-500.

Inglehart, Ronald and Wayne E. Baker. 2000. "Modernization, Cultural Change, and the Persistence of Traditional Values." American Socioligical Review 65:19-51.

Jaeger, M. M. 2009. "Equal Access but Unequal Outcomes:

Cultural Capital and Educational Choice in a Meritocratic Society." Social Forces 87:1943-1971.

Joas, Hans. 2000. The Genesis of Values. Cambridge, UK: Polity Press.

Johnsen, Eugene C. 1986. "Structure and Process: Agreement Models for Friendship Formation." Social Networks 8:257306. 
Johnson, Monica Kirkpatrick. 2001. "Job Values in the Young Adult Transition: Change and Stability with Age." Social Psychology Quarterly 64:297-317.

Keister, Lisa A. 2003. "Religion and Wealth: The Role of Religious Affiliation and Participation in Early Adult Asset Accumulation." Social Forces 82:175-207.

Keister, Lisa A. 2007. "Upward Wealth Mobility: Exploring the Roman Catholic Advantage." Social Forces 85:1195-1225.

Keister, Lisa A. 2008. "Conservative Protestants and Wealth: How Religion Perpetuates Asset Poverty." The American Journal of Sociology 113:1237-1271.

Keister, Lisa A. 2010. "Childhood Religious Denomination and Early Adult Asset Accumulation.” Pp. 164-185 in Religion, Families, and Health: New Directions in Population-Based Research, edited by C. G. Ellison and R. A. Hummer. New Brunswick, NJ: Rutgers University Press.

Kohn, Melvin L. 1959. "Social Class and Parental Values." The American Journal of Sociology 64:337-351.

Kohn, Melvin L. 1976. "Social Class and Parental Values: Another Confirmation of the Relationship." American Sociological Review 41:538-545.

Kohn, Melvin L. and Kazimierz M. Slomczynski. 2001. "Social Structure and Self-Direction: A Comparative Analysis of the United States and Poland." Pp. 73-102 in Self in Society, edited by A. Branaman. Malden, MA: Blackwell.

Kohn, Melvin L., Wojciech Zaborowski, Krystyna Janicka, Bogdan W. Mach, Valeriy Khmelko, Kazimierz M. Slomczynski, Cory Heyman, and Bruce Podobnik. 2000. "Complexity of Activities and Personality under Conditions of Radical Social Change: A Comparative Analysis of Poland and Ukraine." Social Psychology Quarterly 63:187-207.

Lareau, Annette. 2002. "Invisible Inequality: Social Class and Childrearing in Black Families and White Families." American Sociological Review 67:747-776.

Lareau, Annette. 2003. Unequal Childhoods: Class, Race, and Family Life. Berkeley, CA: University of California Press. 
Lehrer, Evelyn. 1995. "The Effects of Religion on the Labor Supply of Married Women." Social Science Research 24:281301.

Lehrer, Evelyn. 1996a. "The Determinants of Marital Stability: A Comparative Analysis of First and Higher Order Marriages." Pp. 91-121 in Research in Population Economics, edited by T. P. Schultz. Greenwich, CT: JAI.

Lehrer, Evelyn. 1996b. "Religion as a Determinant of Fertility." Journal of Population Economics 9:173-196.

Lehrer, Evelyn. 1996c. "The Role of the Husband's Religion on the Economic and Demographic Behavior of Families." Journal for the Scientific Study of Religion 35:145-155.

Lehrer, Evelyn. 1999a. “Married Women's Labor Supply Behavior in the 1990s: Differences by Life-Cycle Stage." Social Science Research 80:574-590.

Lehrer, Evelyn. 1999b. "Religion as a Determinant of Educational Attainment: An Economic Perspective." Social Science Research 28:358-379.

Lehrer, Evelyn. 2000. "Married Women's Labor Supply Behavior in the 1990s: Differences by Life-cycle Stage." Pp. 227-252 in The Ties that Bind: Perspectives on Marriage and Cohabitation, vol. 80, edited by C. B. Linda Waite, M. Hindon, E. Thomson, and A. Thornton. Hawthorne, NY: Aldine de Gruyter.

Lehrer, Evelyn. 2004. "Religion as a Determinant of Economic and Demographic Behavior in the United States." Population and Development Review 30:707-26.

Lehrer, Evelyn. 2009. Religion, Economics, and Demography: The Effects of Religion on Education, Work, and the Family. London, England: Routledge.

Lenski, Gerhard Emmanuel. 1961. The Religious Factor: A Sociological Study of Religion's Impact on Politics, Economics, and Family Life. Garden City, NY: Doubleday. Maio, Greg R., James M. Olson, Mark Bernard, and Michelle A. Luke. 2003. "Ideologies, Values, Attitudes, and Behavior." Pp. 283-308 in Handbook of Social Psychology, edited by J. DeLamater. New York, NY: Kluwer Academic. 
Marcum, John P. 1981. "Explaining Fertility Differences among U.S. Protestants." Social Forces 60:532-543.

Marcum, John P. 1986. "Explaining Protestant Fertility: Belief, Commitment, and Homogamy." Sociological Quarterly 27:547-58.

McQuillan, Kevin. 2004. "When Does Religion Influence Fertility?" Population and Development Review 30:532-543.

Moody, James W. 1998. "Matrix Methods for Calculating the Triad Census." Social Networks 20:291-299.

Muller, Chandra and Christopher Ellison. 2001. "Religious Involvement, Social Capital, and Adolescents' Academic Progress: Evidence from the National Educational Longitudinal Study of 1988." Sociological Focus 34:155-183.

Park, Jerry Z. and Sam H. Reimer. 2002. "Revisiting the Social Sources of American Christianity 1972-1998." Journal for the Scientific Study of Religion 41:733-746.

Peek, Charles W., George D. Lowe, and L. Susan Williams. 1991. "Gender and God's Word: Another Look at Religious Fundamentalism and Sexism." Social Forces 69:1205-1221.

Peifer, Jared L. 2011. "Morality in the financial market? A Look at Religiously Affiliated Mutual Funds in the USA." SocioEconomic Review 9:235-259.

Read, Jen'nan. 2004. Culture, Class, and Work among ArabAmerican Women. New York, NY: LFB Scholarly Publishing.

Reimer, Sam. 2007. "Class and Congregations: Class and Religious Affiliation at the Congregational Level of Analysis." Journal for the Scientific Study of Religion 46:583-594.

Roof, Wade Clark. 1989. "Multiple Religious Switching: A Research Note." Journal for the Scientific Study of Religion 28:530-535.

Roof, Wade Clark and William McKinney. 1987. American Mainline Religion: Its Changing Shape and Future. New Brunswick, NJ: Rutgers University Press.

Samuelsson, Kurt. 1964. Religion and Economic Action: A Critique of Max Weber. New York, NY: Harper \& Row. 
Schwartz, Shalom H. and Wolfgang Bilsky. 1987. "Toward a Theory of the Universal Content and Structure of Values." Journal of Personality and Social Psychology 58:878-891.

Schwartz, Shalom H. and Sipke Huismans. 1995. "Value Priorities and Religiosity in Four Western Religions." Social Psychology Quarterly 58:88-107.

Schwartz, Shalom H., Naomi Struch, and Wolfgang Bilsky. 1990. "Values and Intergroup Social Motives: A Study of Israeli and German Students." Social Psychology Quarterly 53:185-198.

Sherkat, Darren. 2000. "That They Be Keepers of the Home: The Effect of Conservative Religion on Early and Late Transitions into Housewifery." Review of Religious Research 41:344-458.

Sherkat, Darren E. and Alfred Darnell. 1999. "The Effect of Parents' Fundamentalism on Children's Educational Attainment: Examining Differences by Gender and Children's Fundamentalism." Journal for the Scientific Study of Religion 38:23-35.

Smith, Christian and Robert Faris. 2005. "Socioeconomic Inequality in the American Religious System: An Update and Assessment." Journal for the Scientific Study of Religion 44:95-104.

Sombart, Werner. 1911. The Jews and Modern Capitalism.

Translated by M. Epstein. New York, NY: E. P. Dutton and Company.

Steen, Todd P. 1996. "Religion and Earnings: Evidence from the NLS Youth Cohort.” International Journal of Social Economics 23:47-58.

Weber, Max. 2002. The Protestant Ethic and the Spirit of Capitalism. New York, NY: Penguin Books.

Wilder, Esther I. and William H. Walters. 1998. "Ethnic and Religious Components of the Jewish Income Advantage, 1969 and 1989." Sociological Inquiry 68:426-436.

Willis, Paul. 1981. Learning to Labor: How Working Class Kids Get Working Class Jobs. New York, NY: Columbia University Press.

Wuthnow, Robert. 1994. God and Mammon in America. New York, NY: Free Press. 
Zelizer, Viviana. 1978. "Human Values and the Market: The Case of Life Insurance and Death in 19th-Century America." The American Journal of Sociology 84:591-610.

Zelizer, Viviana. 1989. "The Social Meaning of Money: 'Special Monies." The American Journal of Sociology 95:342-377. 